\title{
Correlation of yield with early seedling performance and physio-biochemical traits in Basmati rice mutants subjected to heat stress
}

\author{
Muhammad Ashraf $^{*}$, Zial-ul-Qamar ${ }^{1}$, Amjad Hameed $^{1}$, and Fatma Sarsu ${ }^{2}$ \\ ${ }^{1}$ Nuclear Institute for Agriculture and Biology (NIAB), Faisalabad, Pakistan \\ ${ }^{2}$ International Atomic Energy Agency (IAEA), Vienna, Austria
}

*Corresponding author: ashraflyp@yahoo.com

\begin{abstract}
The present study aims at deciphering the response of Basmati rice mutants to high temperature stress. The work aims to find an early screening method by correlating seedling and physiological response to yields. After rigorous screening in controlled environment (growth chamber) and field conditions over a period of four years 16 mutants' lines were selected: HTT-18, HTT-29, HTT-31, HTT-39, HTT-51, HTT-53, HTT-74, HTT-81, HTT-92, HTT-97, HTT-98, HTT-104, HTT-114, HTT-119, HTT-132 and HTT-138. These have been tested against standards: Super Basmati and IR-64. Field trials were conducted at three locations while early seedling-stage traits and their biochemical analyses were studied in growth chamber experiments. Data of seedling traits were used to establish correlations with paddy yield under hot field conditions. The temperatures were high at two sites: Multan and Bahawalpur ranging $24-46{ }^{\circ} \mathrm{C}$ and $25-45{ }^{\circ} \mathrm{C}$ respectively), and relatively lower at NIAB field station $\left(26-45^{\circ} \mathrm{C}\right.$. The paddy yield was significantly correlated with early seedling-stage traits such as shoot length $\left(0.79^{* *}\right)$, shoot fresh and dry weight $\left(0.48^{*}\right.$ and $\left.0.49^{*}\right)$, and cell membrane thermo-stability $\left(0.60^{* *}\right)$. Additionally, significant higher activities of antioxidants (SOD and APX) and lower stress indicators (MDA, Esterase and TOS) were observed in the heat tolerant mutants. These mutants were classified for their heat tolerance by principle component analysis (PCA) using yield-correlated early seedling-stage and other physio-biochemical parameters. As a result, the heat tolerance classification of mutants based on PCA coincided with the yield of mutants grown under hot field conditions. The present study suggests that these seedling parameters may be used as surrogates for field performance and used in the selection of thermo-tolerant Basmati rice. Our next objective is to screen these thermo-tolerant lines for multiple weather adversities resistance by applying the strategy being reported here.
\end{abstract}

Key Words: High temperature, Basmati rice, seedling trait correlations with yield, antioxidants, paddy yield.

Abbreviations: APX_Ascorbate Peroxidase, SOD_Superoxide Dismutase, CMTS_Cell Membrane Thermo-Stability, POD_Peroxidase, TPC_Total Phenolic Content, TSP_Total Soluble Protein and CAT Catalase, HTT_Heat Temperature Tolerant, PCA_Principle Component Analysis, NIAB_Nuclear Institute for Agriculture and Biology.

\section{Introduction}

The global mean temperature is rising every year and it is predicted that by 2100 it will be $3.7^{\circ} \mathrm{C}$ higher than present (IPCC, 2013). The current global climate predictions are expected to adversely affect rice production by up to $25-32 \%$ (Wassmann et al., 2009; Ray et al., 2015; Van Oort and Zwart, 2018). Increased daytime temperatures of more than $34^{\circ} \mathrm{C}$ will depress rice yield by $8 \%$ (Bahuguna et al., 2015; Shi et al., 2014). In 2003, about 5.2 million tons of paddy rice was lost due to a heat wave with temperatures above $38^{\circ} \mathrm{C}$ for more than 20 days (Xia and Qi, 2004; Yang et al., 2004). Rice is differentially sensitive to temperature stress at seedling to grain filling stages, and 83,53 and 11\% losses in rice yield have been reported when heat stress was imposed at panicle exertion, early grain filling and late grain filling stages (Ali et al., 2018) whereas Kumar et al. (2015) reported losses in yield (9-55\%) in rice genotypes when subjected to heat stress from anthesis to maturity. A significant influence of high temperature has been observed on seedling traits including a decline in shoot dry mass, relative growth rate and net assimilation rate (Prasanth et al., 2012). Sailaja et al. (2015) reported negative impacts of cell membrane injury on yield in rice. High temperature resulted in electrolyte leakage and ultrastructural modification of the cell membrane system (Zhang et al., 2009; Liu et al., 2013). Heat stress induced changes in membrane fluidity and the production of free radicals resulting in the loss of membrane integrity and ion leakage in different crop plants (Wahid et al., 2007; Bita and Gerats, 2013; Ali et al.
2013; Sailaja et al. 2015). The severity of reactive oxygen species (ROS) induced damage depends on the antioxidant status of the plant (Mohammed and Tarpley, 2009) and under environmental stress, the increased production of active oxygen species reduces the protective activity of antioxidants (Shah et al., 2011; Shalata and Neuman, 2001). Thus, along with several other factors, oxidative stress damage caused by high temperature disrupts growth and development of rice plants (Mohammed and Tarpley, 2011). Many studies demonstrate that elevated temperature injury is caused by excessive production of reactive oxygen radicals and consequent low activities of antioxidant enzymes and membrane damage in plants (Zhang et al., 2006; Zhu et al., 2005). Plants with the ability to scavenge and/or control the level of cellular ROS may be able to withstand heat stress (Almeselmani et al., 2006; Bita and Gerats, 2013), and naturally higher levels of antioxidant enzymes in a plant may be considered as an aid to combat high temperature stress (Bahuguna et al., 2016; Ramesh et al. 2017). Cao et al. (2009) suggested that the relatively higher yields in heat tolerant rice genotypes under high temperature are associated with high levels of activities of ATPase and antioxidant enzymes.

Plant breeders strive extensively to find simple, quick and reproducible screening methods to identify heat-resistant plants from segregating populations and germplasm stocks. Even if paddy yields are accepted as the most suitable trait for identification of rice under high-temperature conditions, the screening for thermo-tolerant rice in the field conditions is labor intensive, time consuming and takes up valuable land. 
Therefore, pre-screening under controlled conditions with rapid, efficient and reproducible approaches is required, e.g. at early developmental stages. Higher temperature significantly reduced the rice yield under field conditions (Ohe et al., 2007; Shah et al., 2014; Jumiatun et al., 2016; Chaturvedi et al., 2017; Yang et al., 2017). Screening for heat tolerance in the field presents a challenge due to interactions with other environmental factors and certain genotypes are required that are adapted to that environment, thus precluding the screening of exotic germplasm. Nevertheless, given these constraints, a wide range of traits are available that may allow successful selection in the field (Hall, 2011). However, attempts had been made in different crop plants to identify thermo-tolerant genotypes using yield-correlated early-stage traits (Demirel et al., 2016).

Heat tolerance to seedlings is critical for adequate crop establishment. The aim of the study was to investigate correlations between early morpho-physiological stage traits and paddy field yield.

\section{Results}

\section{Seedling stage screening in a growth chamber}

The average maximum temperature for the whole growing season (June-November) is presented in fig. 1. The average temperature at NIAB, Faisalabad was $36.3^{\circ} \mathrm{C}, 36.9^{\circ} \mathrm{C}$ at Multan and $37.5^{\circ} \mathrm{C}$ at Bahawalpur while minimum temperature at NIAB, Faisalabad was $27.3^{\circ} \mathrm{C}$ as compared to Multan $\left(28.9^{\circ} \mathrm{C}\right)$ and Bahawalpur $\left(24.9^{\circ} \mathrm{C}\right)$. The mean relative humidity at NIAB, Faisalabad was $62.9 \%, 55.5 \%$ at Multan and $53.8 \%$ at Bahawalpur. The total rainfall recorded during the growing season at NIAB, Faisalabad was $585.2 \mathrm{~mm}, 170.2 \mathrm{~mm}$ at Multan and $77.0 \mathrm{~mm}$ at Bahawalpur. The cell membrane thermo-stability (CMTS) presented in Fig 2 at normal temperature $\left(28 \pm 2{ }^{\circ} \mathrm{C}\right)$ ranged from $84.2-93.0 \%$ with a mean of $88.4 \%$ among the mutants. The controls had high values: Super Basmati $(92.7 \%)$ and IR-64 (93.0\%). However, CMTS decreased 20-42\% with a mean of $27 \%$ at high temperature stress $(45 \pm 2 \circ \mathrm{C})$. At high temperature, the CMTS ranged from 50.6 - 74.2\% with a mean of $64.2 \%$ among the mutants as compared to Super Basmati (55.7\%) and IR-64 (42.0\%).

The shoot length stress tolerance index (SLSTI) varied among the mutants (Table 1$)$ and the maximum value $(87.2 \%)$ was noted in Heat Temperature Tolerant (HTT) mutant HTT-18 whereas mutant HTT-29 maintained the minimum value of $73.9 \%$ as compared to Super Basmati (74.9\%) and IR-64 (75.8\%). For RLSTI, the values ranged from $80.9 \%$ (HTT-53) to $108.9 \%$ (HTT-98) as compared to Super Basmati (86.5\%) and IR-64 $(84.2 \%)$. The maximum values of STI for shoot fresh and dry weights (76.4 and 80.4\%, respectively) were observed in HTT132 and HTT-97 while the minimum STIs of 72.6 and $73.9 \%$, respectively were noted in HTT-31 and HTT-29 as compared to Super Basmati (75.2 and 74.9\%, respectively) and IR-64 (75.0 and $75.8 \%$ respectively). For root fresh and dry weights, the maximum STIs for root fresh and dry weights were noted 87.3 and $64.6 \%$, respectively in HTT-97 and HTT-114 whereas HTT31 and HTT-51 maintained the minimum values of 82.5 and $54.8 \%$, respectively as compared to Super Basmati (85.8 and $57.8 \%$, respectively) and IR-64 (87.0 and 60.5\%), respectively. The maximum CMTS was observed in HT'T-18 (80.1\%) whereas the least was noted in HTT-132 (58.5\%) as compared to Super Basmati (60.1\%) and IR-64 (44.7\%).

Stress tolerance indices (Table 2) showed that mutant HTT-18 had the highest score (8.72) for shoot length while the minimum score (7.39) was noted in HTT-29 as compared to Super Basmati (7.49) and IR-64 (7.58). The maximum score (18.15) for root length was observed in mutant HTT-98 whereas the minimum score (13.48) was obtained by HTT-53 as compared to Super Basmati (14.42) and IR-64 (14.04). Mutant HTT-98 obtained the highest score of 6.27 for shoot fresh weight whilst HT'T-31 had a score of 6.05 as compared to Super Basmati (6.27) and IR-64 (6.25). For shoot dry weight, the maximum score was noted in HTT-97 (8.04) whereas HT'T-29 had the minimum score of 7.39 as compared to Super Basmati (7.49) and IR-64 (7.58). HTT-97 showed the highest score (6.72) for root fresh weight and the minimum was 6.35 in HTT-31 as compared to Super Basmati (6.60) and IR-64 (6.69). The maximum (4.97) and the minimum (4.22) scores for root dry weight were noted in mutants HTT114 and HTT-51, respectively as compared to Super Basmati (4.44) and IR-64 (4.65). The highest score (24.02) for CMTS was noted in HTT-18 while the minimum was 17.56 in HTT-132 as compared to Super Basmati (18.03) and IR-64 (13.40). On a cumulative basis of the scores, mutant HTT-98 obtained the highest score of 75.12 while the least was 71.10 obtained from HTT-97 and these were higher than the standards, Super Basmati (64.74) and IR-64 (60.20). Based on seedling growth traits, none of the mutants were categorized as sensitive to heat stress (as expected, as the mutants under study were selected after years of testing (2012-14) and reported as having better responses to heat stress, (Zafar et al., 2017). Ten mutants HTT-98, HTT-18, HTT51, HTT-29, HT'-97, HTT-39, HTT-92, HTT-119, HTT-81, and HTT-31 exhibiting cumulative scores of 73 and above showed tolerance to heat stress as compared to Super Basmati (68.06) exhibiting moderately tolerant and IR-64 (62.82) showing sensitive behavior to high temperatures.

The correlation analysis (Table 3) among different seedling growth parameters and yield under high temperature stress indicated highly significant positive correlations of shoot length with CMTS, shoot fresh weight with shoot dry weight, and root fresh weight with root dry weight, however, CMTS had negative associations with root fresh and dry weights. Paddy yield exhibited highly significant correlations with shoot length, shoot fresh and dry weights, and CMTS, however, root dry weight showed negative correlation with paddy yield.

The principal component analysis (PCA) was performed to reveal the pattern and clustering of data matrix for determination and identification of selection criteria. The results explained the genetic diversity among the rice mutants (Table 4). From the PCA, first three principal components with eigenvalue $>1$ were selected, and these components accounted for more than $90 \%$ of the cumulative variance. The remaining components were eliminated and considered less significant. Based on the component loadings after varimax rotation, the first two components were extracted, and the other components were eliminated. These two principal components accounted for $82.8 \%$ of the total variance of the original data and the communalities showed that all the variables had been described to an acceptable level as communalities ranged from 0.722 to 0.959. The first component gave information on variation in shoot length, root dry weight, CMTS and paddy yield which described more than $53.1 \%$ of the variance. In this component, shoot length, root dry weight and CMTS were observed as more important for the improvement of rice paddy yield. The second component described about 30\% variation, which originated mainly from shoot fresh and dry weight. To classify the mutants for their heat tolerance, the values of yield-correlated traits like shoot length, shoot fresh and dry weight, root dry weight and CMTS were used in the PCA. The first two vectors (PC1 and PC2) accounted for $82.8 \%$ of total variation. The mutants were classified into four groups based on PC1 and PC2 values (Fig 3). The mutants with +PC1 and + PC2 were graded as tolerant, with +PC1 and -PC2 as moderately tolerant, with -PC1 and +PC2 as moderately susceptible, and with -PC1 and -PC2 as susceptible. According to this classification, the mutants HTT53, HT'T-92, HTT-97 and HTT-98 were graded as tolerant, and HTT-18, HT'T-29, HT'T-31, HT'T-39, HTT-74 and HT'-

\section{0 | Page}


81 as moderately tolerant mutants. However, Super Basmati and IR-64 exhibited moderately susceptible to susceptible response.

\section{Biochemical analysis}

The enzymatic and non-enzymatic antioxidants along with other important biochemical attributes were analyzed to understand the mechanism of heat tolerance in rice mutants.

\section{Stress biomarkers}

The oxidative damage during peroxidation of membrane lipids is often estimated by the quantification of malondialdehyde (MDA) production. The MDA contents among the mutants (Fig 4.A) generally increased under heat stress as compared to control conditions, however, some of the mutants maintained the MDA contents under the both conditions (HTT-31 and HTT-138) or decreased under heat stress (HTT-18, HTT-97 and HTT-104). The increased MDA level indicated that the production of reactive oxygen species (ROS) was greater under heat stress than control conditions. The highest stress-induced increase in MDA contents was observed in HT'T-119. A relatively higher MDA content was also observed in heat sensitive mutants while the level was low in heat tolerant mutants under normal conditions. It indicates that MDA content can be simply used for potential heat stress tolerance in normal conditions. The total oxidant status (TOS) decreased under heat stress, however, some of the mutants showed higher status of TOS as compared to their respective control conditions (Fig 4. J). The highest TOS was observed in HTT-18 under heat stress and also it showed the maximum value of TOS among the mutants under heat stress whereas the highest reduction of TOS was observed in mutant HTT-138. Based on relative tolerance responses, five mutants HTT-104, HTT-97 HTT-98, HTT-31 and HTT-18 showed promise against heat stress as compared to Super Basmati.

\section{Enzymatic antioxidants}

For scavenging ROS in plants, two types of antioxidant systems (enzymatic and non-enzymatic) were deployed. The peroxidase (POD) and catalase (CAT) are the key enzymes along with superoxide dismutase (SOD) and others. The POD activity (Fig 4.B) reduced as a result of heat stress in all the mutants with varying degree of decrease. The highest POD activity under heat stress was observed in HTT-39 with least decrease (12\%) as compared to control conditions whereas the highest stressinduced increase in POD activity was exhibited by HTT-98 and HTT-104. The CAT activity (Fig 4.C) generally decreased under heat stress as compared to control conditions, however, in some of the mutants, the CAT activity increased with maximum value in HTT-18 followed by HTT-29 and HTT-98. The SOD activity (Fig 4.D) increased slightly under heat stress as compared to normal conditions, however, some of the mutants showed lower levels of SOD activity as compared to their respective controls. The highest SOD activity under heat stress was observed in HTT-98 whereas the lowest SOD activity was observed in HT'T114. Heat stress enhanced the ascorbate peroxidase (APX) activity among the mutants (Fig 4.F); however, some of the mutants (HTT-18, HT'T-29, HTT-53 and HTT-81) showed less APX activity as compared to their respective control conditions. The highest APX activity under heat stress was observed in HTT-51.

\section{Non-enzymatic antioxidants}

The total phenolic content (TPC) generally decreased under heat stress (Fig 4.E), however, mutants HTT-18 and HTT-39 exhibited higher TPC contents, and mutants HTT-29 and HTT119 maintained the TPC contents under stress and normal conditions. The highest stress-induced incline in TPC contents was observed in HTT-132.

\section{Hydrolytic enzymes}

Esterase activity decreased very slightly under heat stress (Fig 4.G), however, most of the mutants exhibited higher esterase activity compared to their respective control conditions. The highest stress-induced incline in esterase activity was detected in HTT-51 and increase in HTT-114.The protease activity generally decreased under heat stress (Fig 4.H). The maximum protease activity under heat stress was observed in HTT-138, however, HTT-81 exhibited the least decrease as compared to other mutants under heat stress. Biochemical attributes

The total soluble protein (TSP) content decreased in all the mutants except in mutants HTT-29 and HTT-31 where TSP contents increased under heat stress (Fig 4. I). The highest decrease in TSP contents under heat stress was observed in HTT-132 whereas the least decrease was noted in HT'T-119.

\section{Principal component analysis based on biochemical indices}

For classification of the mutants for their heat tolerance, the values of yield-correlated traits such as POD, TPC, CAT, MDA, TSP, and TOS were used in the PCA (Table 5). The first four vectors (PC1-PC4) accounted for $85.5 \%$ of total variation. The mutants were classified into four groups based on first and second factor values (Fig 5). The mutants with + PC1 and +PC2 were graded as tolerant, with $+\mathrm{PC} 1$ and $-\mathrm{PC} 2$ as moderately tolerant, with $-\mathrm{PC} 1$ and $+\mathrm{PC} 2$ as moderately susceptible, and with -PC1 and -PC2 as susceptible. According to this classification, the mutants HTT-92, HTT-114 and HTT-119 were graded as tolerant, and HTT-18, HTT-29, HTT-74 and HTT-81 as moderately tolerant mutants.

\section{Field experiments}

The mutants along with standards were studied under field conditions with varying temperatures at NIAB Faisalabad, Multan and Bahawalpur. Although the temperatures at all the locations were on the high side, those at Multan and Bahawalpur were higher than at NIAB overall growth stages (from vegetative to maturity). The analysis of variance showed highly significant differences among genotypes for paddy yield and other related agronomic traits at all locations except for productive tillers plant $^{-1}$ at Bahawalpur (Table 6). There was a significant difference among different locations for paddy yield. The mutants showed significant differences in paddy yield. Paddy yield at NIAB was adversely correlated with other locations (Fig 6) suggesting that high potential yield at NIAB did not necessarily result in improved yield under stressful locations. Overall, 38\% paddy yield reduced at Multan and $31 \%$ at Bahawalpur as compared to NIAB. The mean paddy yields ranged from 2,583 to $4,567 \mathrm{~kg} \mathrm{ha}^{-1}$ at NIAB, 1,357 to $3,163 \mathrm{~kg} \mathrm{ha}^{-1}$ at Bahawalpur and 2,241 to 2,683 $\mathrm{kg} \mathrm{ha}^{-1}$ at Multan. All the mutants produced lesser paddy yields at Bahawalpur and Multan as compared to NIAB. Among the mutants, the paddy yield declined $10-70 \%$ at Multan whereas at Bahawalpur the decline was $4-57 \%$. The highyielding mutants HTT-18 produced the highest paddy yield $\left(4,567 \mathrm{~kg} \mathrm{ha}^{-1}\right)$ at NIAB followed by HTT-74 $\left(4,556 \mathrm{~kg} \mathrm{ha}^{-1}\right)$ and HTT-29 $\left(4,059 \mathrm{~kg} \mathrm{ha}^{-1}\right)$ as compared to standards Super Basmati (3408 $\left.\mathrm{kg} \mathrm{ha}^{-1}\right)$ and IR-64 (3228 kg ha-1). The mutant HTT-74 showed higher reduction in paddy yield $(70 \%)$ followed by HTT$29(49 \%)$ and HTT-18 (38\%) at Multan as compared to Super Basmati (46\%) and IR-6 (37\%) whereas at Bahawalpur, the mutant HTT-74 showed 35\% reduction in paddy yield followed by HTT-18 (31\%) and HTT-29 (29\%) as compared to Super Basmati (23\%) and IR-64 (54\%). 


\section{Discussion}

High temperature stress is one of the major factors affecting plant growth and development (Howarth, 2005; Sailaja et al., 2014; Tayade et al., 2018). The crucial limitation for breeding high-yielding heat tolerant rice cultivars is the lack of reliable screening techniques. A multi-trait approach may be needed owing to the nature of heat tolerance as a complex phenotypic trait under the control of multiple physiological and genetic factors (Wahid et al., 2007; Collins et al., 2008; Ainsworth and Ort, 2010; Sailaja et al., 2015; Tayade et al., 2018). Screening must reflect yield performance of genotypes grown under hot field conditions. Screening at early developmental stages under controlled environmental conditions is preferred due to its advantages of applicability in the off-season and in a short time, testing potential in non-adapted germplasm, saving land space, labor and inputs. The identification of yield-related early seedling/physiological traits at an early seedling-stage has been of great interest to physiologists and breeders (Demirel et al., 2016; Sailaja et al., 2015). Thus, we aimed at to develop an early stage screening technique by investigating yield-related early seedling-stage/physiological traits (shoot and root lengths, their fresh and dry weights and cell membrane thermo-stability), as well as biochemical attributes (enzymatic and non-enzymatic antioxidants, stress biomarkers and hydrolytic enzymes etc.). Principle component analysis was performed to identify productive thermo-tolerant mutants.

The present study revealed that seedling traits were significantly influenced by high temperature. In general, high temperature treatment reduced shoot/root lengths and their respective fresh and dry weights, and the cell membrane thermo-stability (CMTS). The adverse effects of high temperature on seedling growth traits and CMTS in rice has been observed by other researchers (Prasanth et al., 2012; Zhou et al., 2012; Ali et al., 2013; Sailaja et al., 2014; Zafar et al., 2017). All seedling growth traits significantly varied among the mutants under both control and stress conditions. However, only root dry weight (RDW) under high temperature was adversely correlated with paddy yield grown under hot field conditions. The study indicated that high temperature decreased root dry weight. Similarly, early seedling growth traits in rice had been negatively affected in response to high temperature (Zhou et al., 2012), therefore, for pre-screening of rice with high yield in hot field conditions, shoot length, and its fresh and dry weight and CMTS may be evaluated together with other yield-associated traits applying multi-level screening approach.

Based on data sets of the previous studies conducted for Indica seedling traits in 46 genotypes including 39 mutants, the mutants were characterized as moderately tolerant to tolerant (Zafar et al., 2017). Among these, 16 mutants that produced higher paddy yield $(2-31 \%$ higher than standard) were further tested for seedling growth traits as well as for their yield performance under field conditions at three locations. The relative heat tolerance of the mutants was assessed based on various seedling growth/physiological traits and field conditions. The data from seedling growth traits and yield data obtained from the hot field conditions (see section on weather) were used for correlation analysis. According to the correlation analysis, shoot length and its fresh and dry weights, root dry weight and CMTS were correlated with yield performance under hot field conditions. Afterwards, the mutants were classified for their thermotolerance by PCA using all yield-correlated traits. PCA is considered as a useful statistical tool for screening multivariate data which are highly correlated with each other (Johnson, 1998). Use of PCA to classify rice genotypes for heat tolerance has been recommended by several researchers (Kakani et al., 2005; Liu et al., 2006). The PCA results showed considerable similarity to yield performance of the mutants under hot field conditions with the performance of seedling growth traits. The first component represented the significance of this PC for heat related traits such as shoot length and CMTS. The mutants having vigorous shoots and higher CMTS may be considered as selection criteria under hot field condition. The mutants HTT-18, HTT-29, HTT-31, HTT-39, HT'T-51, HTT-74 and HTT-81 exhibited larger shoots as well as better yield under hot conditions. Based on PCA results, mutants HTT-53, HTT-92, HTT-97 and HTT-98 were classified as tolerant, HTT-18, HTT-29, HTT-31, HT'-39, HTT-51, HTT-74 and HTT-81 as moderately tolerant, HTT104, HTT-119 and Super Basmati as moderately susceptible. The remaining three mutants HTT-114, HTT-132 and HTT-138 along with standard IR-64 were classified as susceptible. According to the productivity under hot field conditions, the mutants HTT-18, HTT-29, HTT-31, HTT-39, HTT-51, HTT74 and HTT-81 were considered as heat tolerant. Interestingly, the classification of mutants based on PCA using shoot length, and its fresh and dry weight and CMTS coincided neatly with the heat tolerance level of mutants grown in the hot field conditions. The important characters coming together in different PCs tended to remain together, which may be kept into consideration during utilization of these characters in thermo-tolerance breeding programmes to bring about rapid improvement for yield and other associated traits. The leaf related traits are very important in thermo-tolerance because the major part of the starch in rice grains at harvest is the photosynthetic product of the leaves (source), which is translocated from the leaves directly to the growing grains (Venkateswarlu and Visperas, 1987).

Field screening for heat stress is difficult due to variation in environmental conditions like humidity and temperature. Alternatively, screening for heat stress tolerance may be done on the basis of various biochemical parameters such as malondialdehyde (MDA), SOD, CAT, POD, APX, TSP content and protease (Kang and Saltveit, 2002; Maestri et al., 2002; Iqbal et al., 2010; Hameed et al., 2012; Ramesh et al., 2017). Heat stress affects the biochemistry of the plants and the activities of antioxidant enzymes increased significantly in the heat tolerant varieties (Cao et al., 2009). High temperature stress caused upregulation of several heat responsive genes which code for numerous heat shock proteins (Charng et al., 2007). In the present study, the level of TSP fell under heat stress in most of the mutants. TSP content was also reported to be decreased under heat stress in wheat (Hameed et al., 2012). An effective heat tolerance mechanism at sensitive stages of plant growth can be adopted by protecting the structural proteins, membranes and different enzymes from damage by heat shock. HSPs and some other stabilizing factors might play important role in these processes related to heat tolerance (Maestri et al., 2002).

The PCA results showed considerable similarity to yield performance of the mutants under hot field conditions with the antioxidant activities. The first component represented the significance of this PC for heat related traits such as TPC and TOS. The higher activities of protective enzymes in the antioxidant system in plants might be one of the physiological mechanisms for heat tolerance in rice (Ramesh et al., 2017). The mutants exhibiting higher TPC and TOS may be considered in selection under hot field condition. The mutants HTT-18, HTT29, HTT-39, HTT-92 and HTT-114 exhibited higher levels of TPC or TOS as well as better yield under hot conditions. Based on PCA results, mutants HTT-18, HTT-29, HTT-74, HTT-81, HTT-92, HTT-114 and HTT-119 were classified as tolerant to moderately tolerant and rest of the mutants were classified as susceptible to moderately susceptible. 
Table 1. Range (maximum and minimum) of different stress tolerance indices (STIs) in Basmati mutants with respect to their responses to high temperature stress in the growth chamber

\begin{tabular}{|c|c|c|c|c|c|c|c|}
\hline \multirow[t]{2}{*}{ Mutant } & \multicolumn{7}{|c|}{ Stress Tolerance Index (\%) } \\
\hline & SL & RL & SFW & SDW & RFW & RDW & CMTS \\
\hline HTT-18 & $87.2^{\mathrm{A}}$ & $95.1^{\mathrm{B}}$ & $74.8^{\mathrm{ABCD}}$ & $74.9 \mathrm{CDE}$ & $86.5^{\mathrm{BCDE}}$ & $59.0^{\mathrm{DE}}$ & $80.1^{\mathrm{A}}$ \\
\hline HTT-29 & $73.9^{\mathrm{G}}$ & $95.7^{\mathrm{B}}$ & $75.3^{\mathrm{ABCD}}$ & $73.9^{\mathrm{A}}$ & $85.9 \mathrm{EF}$ & $55.7 \mathrm{GH}$ & $78.6^{\mathrm{AB}}$ \\
\hline HTT-31 & $75.8^{\mathrm{FG}}$ & $82.8^{\mathrm{GHI}}$ & $72.6^{\mathrm{E}}$ & $75.8^{\mathrm{BCD}}$ & $82.5^{\mathrm{H}}$ & $55.8^{\mathrm{GH}}$ & $79.1^{\mathrm{AB}}$ \\
\hline HTT-51 & $74.7 \mathrm{G}$ & $94.7^{\mathrm{BC}}$ & $75.8^{\mathrm{ABC}}$ & $74.8^{\mathrm{CDE}}$ & $86.9^{\mathrm{ABC}}$ & $54.8^{\mathrm{H}}$ & $78.4^{\mathrm{AB}}$ \\
\hline HTT-53 & $75.9 \mathrm{FG}$ & $80.9^{\mathrm{I}}$ & $75.7 \mathrm{ABC}$ & $75.8^{\mathrm{BCD}}$ & $86.2^{\mathrm{DEF}}$ & $57.7 \mathrm{EF}$ & $75.0^{\mathrm{CD}}$ \\
\hline HTT-97 & $80.4^{\mathrm{CD}}$ & $95.1^{\mathrm{B}}$ & $76.2^{\mathrm{AB}}$ & $80.3^{\mathrm{A}}$ & $87.3^{\mathrm{A}}$ & $57.3 \mathrm{EFG}$ & 72.3DEF \\
\hline HTT-98 & $76.0^{\mathrm{FG}}$ & $108.8^{\mathrm{A}}$ & $75.2^{\mathrm{ABCD}}$ & $76.1^{\mathrm{BC}}$ & 86.1 $1 \mathrm{DEF}$ & $64.0^{\mathrm{AB}}$ & $79.9^{\mathrm{A}}$ \\
\hline HTT-114 & 76.7 $\mathrm{EFG}$ & $93.6^{\mathrm{BC}}$ & $76.1^{\mathrm{AB}}$ & $76.8^{\mathrm{B}}$ & $87.1^{\mathrm{AB}}$ & $64.6^{\mathrm{A}}$ & $64.5^{\mathrm{G}}$ \\
\hline HTT-132 & $75.9 \mathrm{FG}$ & $107.6^{\mathrm{A}}$ & $76.4^{\mathrm{A}}$ & $75.9^{\mathrm{BCD}}$ & 86.1DEF & $63.4^{\mathrm{AB}}$ & $58.5^{\mathrm{I}}$ \\
\hline Super Basmati & $74.9^{\mathrm{G}}$ & $86.6^{\mathrm{E}}$ & $75.2^{\mathrm{ABCD}}$ & 74.9CDE & $85.8^{\mathrm{F}}$ & $57.8^{\mathrm{EF}}$ & $60.1^{\mathrm{HI}}$ \\
\hline IR-64 & $75.8^{\mathrm{FG}}$ & $84.2^{\mathrm{FG}}$ & $75.0^{\mathrm{ABCD}}$ & $75.8^{\mathrm{BCD}}$ & $87.0^{\mathrm{ABC}}$ & $60.5^{\mathrm{CD}}$ & $45.2 \mathrm{~J}$ \\
\hline
\end{tabular}

SL: Shoot length, RL: Root length, SFW: Shoot fresh weight, SDW: Shoot dry weight, RFW: Root fresh weight, RDW: Root dry weight, CMTS: Cell membrane thermo-stability

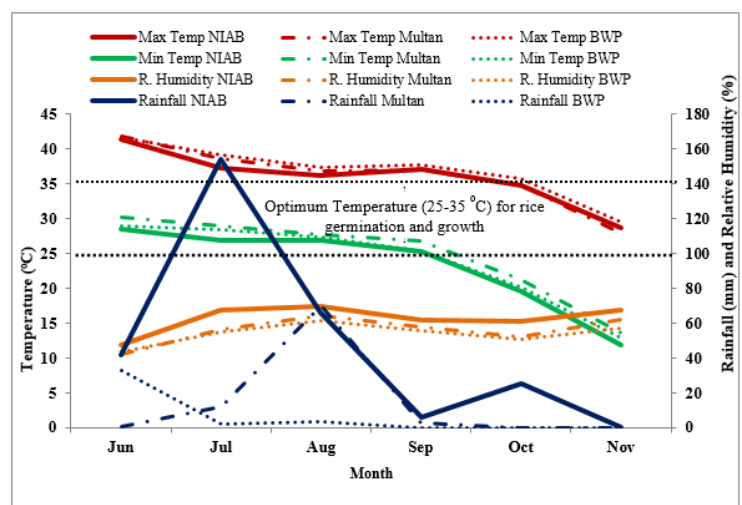

Fig 1. Mean temperature, rainfall and relative humidity for whole rice growing season at NIAB, Multan and Bahawalpur during 2016.

Table 2. Range (maximum and minimum) of scores obtained on the basis of different stress tolerance indices for different seedling growth traits in Basmati mutants.

\begin{tabular}{|l|c|c|c|c|c|c|c|c|}
\hline & \multicolumn{9}{c}{ Sutant } & SL & RL & SFW & SDW & RFW & RDW & CMTS & $\begin{array}{c}\text { Total } \\
\text { Score }\end{array}$ \\
\hline HTT-18 & $8.72^{\mathrm{A}}$ & $15.85^{\mathrm{B}}$ & $6.23^{\mathrm{ABCD}}$ & $7.49^{\mathrm{CDE}}$ & $8.65^{\mathrm{BCDEF}}$ & $5.90^{\mathrm{DE}}$ & $24.03^{\mathrm{A}}$ & 76.9 \\
\hline HTT-29 & $7.39^{\mathrm{G}}$ & $15.94^{\mathrm{B}}$ & $6.28^{\mathrm{ABCD}}$ & $7.39^{\mathrm{E}}$ & $8.59^{\mathrm{G}}$ & $5.57^{\mathrm{GH}}$ & $23.58^{\mathrm{AB}}$ & 74.7 \\
\hline HTT-31 & $7.58^{\mathrm{FG}}$ & $13.79^{\mathrm{EFG}}$ & $6.05^{\mathrm{E}}$ & $7.58^{\mathrm{BCD}}$ & $8.25^{\mathrm{I}}$ & $5.58^{\mathrm{FGH}}$ & $23.74^{\mathrm{AB}}$ & 72.6 \\
\hline HTT-51 & $7.47^{\mathrm{G}}$ & $15.78^{\mathrm{B}}$ & $6.31^{\mathrm{AB}}$ & $7.48^{\mathrm{CDE}}$ & $8.69^{\mathrm{ABC}}$ & $5.48^{\mathrm{H}}$ & $23.53^{\mathrm{AB}}$ & 74.7 \\
\hline HTT-53 & $7.59^{\mathrm{FG}}$ & $13.49^{\mathrm{G}}$ & $6.31^{\mathrm{AB}}$ & $7.58^{\mathrm{BCD}}$ & $8.62^{\mathrm{DEFG}}$ & $5.77^{\mathrm{EFG}}$ & $22.49^{\mathrm{CD}}$ & 71.8 \\
\hline HTT-97 & $8.04^{\mathrm{CD}}$ & $15.85^{\mathrm{B}}$ & $6.35^{\mathrm{AB}}$ & $8.03^{\mathrm{A}}$ & $8.73^{\mathrm{A}}$ & $5.73^{\mathrm{EFG}}$ & $21.68^{\mathrm{DEF}}$ & 74.4 \\
\hline HTT-98 & $7.60^{\mathrm{FG}}$ & $18.13^{\mathrm{A}}$ & $6.27^{\mathrm{ABCD}}$ & $7.61^{\mathrm{BC}}$ & $8.61^{\mathrm{EFG}}$ & $6.40^{\mathrm{AB}}$ & $23.96^{\mathrm{A}}$ & 78.6 \\
\hline HTT-114 & $7.67^{\mathrm{EFG}}$ & $15.60^{\mathrm{BC}}$ & $6.34^{\mathrm{AB}}$ & $7.68^{\mathrm{B}}$ & $8.71^{\mathrm{AB}}$ & $6.46^{\mathrm{A}}$ & $19.36^{\mathrm{G}}$ & 71.8 \\
\hline HTT-132 & $7.59^{\mathrm{FG}}$ & $17.3^{\mathrm{A}}$ & $6.36^{\mathrm{A}}$ & $7.59^{\mathrm{BCD}}$ & $8.61^{\mathrm{FG}}$ & $6.34^{\mathrm{AB}}$ & $17.56^{\mathrm{I}}$ & 72.0 \\
\hline Super Basmati & $7.49^{\mathrm{G}}$ & $14.43^{\mathrm{DE}}$ & $6.27^{\mathrm{ABCD}}$ & $7.49^{\mathrm{CDE}}$ & $8.58^{\mathrm{G}}$ & $5.78^{\mathrm{EF}}$ & $18.02^{\mathrm{HI}}$ & 68.1 \\
\hline IR-64 & $7.58^{\mathrm{FG}}$ & $13.0^{\mathrm{G}}$ & $6.25^{\mathrm{ABCD}}$ & $7.58^{\mathrm{BCD}}$ & $8.70^{\mathrm{ABC}}$ & $6.05^{\mathrm{CD}}$ & $13.55 \mathrm{~J}$ & 62.8 \\
\hline
\end{tabular}

SL: Shoot length, RL: Root length, SFW: Shoot fresh weight, SDW: Shoot dry weight, RFW: Root fresh weight, RDW: Root dry weight, CMTS: Cell membrane thermo-stability.

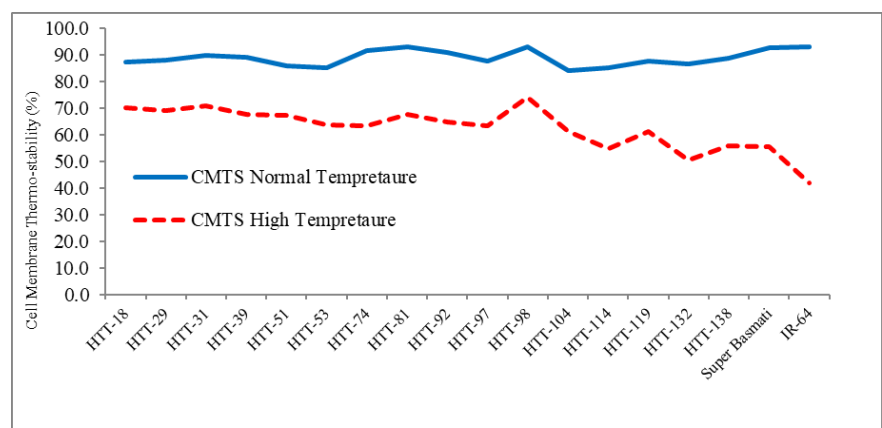

Fig 2. Cell Membrane Thermo-stability (CMTS) (\%) in Basmati rice mutants.

\section{3 | Page}


Table 3. Correlations among different stress tolerance indices of various seedling growth traits in Basmati rice mutants

\begin{tabular}{|c|c|c|c|c|c|c|c|}
\hline \multirow[t]{2}{*}{ Parameter } & \multicolumn{7}{|c|}{ Seedling growth traits } \\
\hline & $\begin{array}{l}\text { Shoot } \\
\text { Length }\end{array}$ & $\begin{array}{l}\text { Root } \\
\text { Length }\end{array}$ & $\begin{array}{c}\text { Shoot Fresh } \\
\text { Weight }\end{array}$ & $\begin{array}{l}\text { Shoot Dry } \\
\text { Weight }\end{array}$ & $\begin{array}{c}\text { Root Fresh } \\
\text { Weight }\end{array}$ & $\begin{array}{l}\text { Root Dry } \\
\text { Weight }\end{array}$ & $\begin{array}{l}\text { Cell Membrane } \\
\text { Thermo-stability }\end{array}$ \\
\hline Root length & 0.291 & & & & & & \\
\hline Shoot Dry Weight & 0.412 & 0.122 & $0.973 * *$ & & & & \\
\hline Root Fresh Weight & -0.210 & -0.202 & 0.247 & 0.182 & & & \\
\hline Root Dry Weight & -0.392 & 0.008 & 0.051 & 0.025 & $0.652 * *$ & & \\
\hline Paddy Yield & $0.794^{* *}$ & 0.357 & $0.477^{*}$ & $0.487^{*}$ & -0.383 & $-0.560 *$ & $0.595^{* *}$ \\
\hline
\end{tabular}

*: Significant at $5-10 \%$.

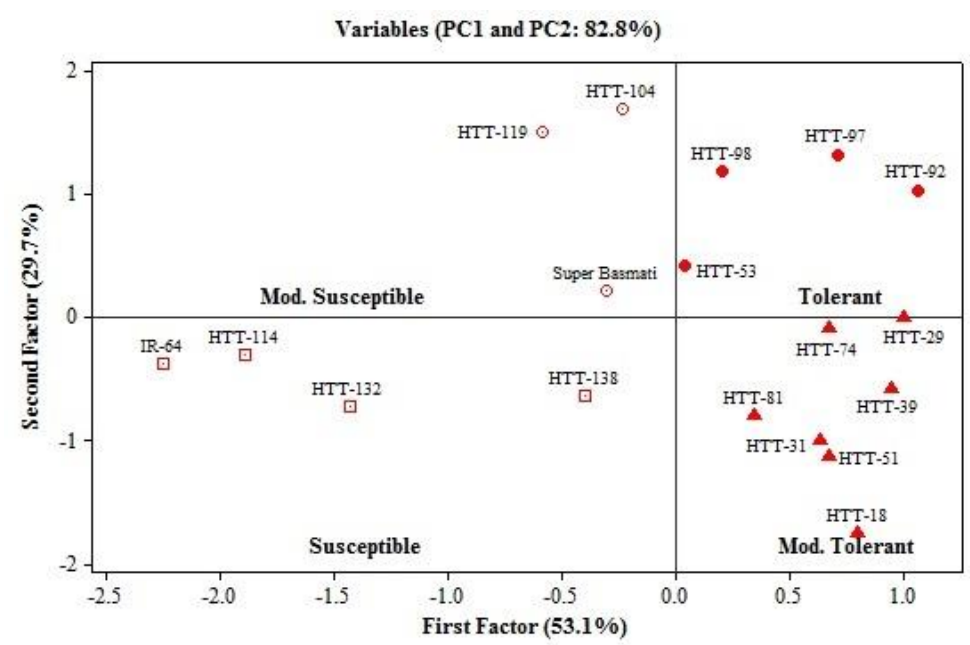

Fig 3. Classification of Basmati rice mutants based on yield-correlated early-stage seedling traits through PCA. Mutants that had + PC1 and $+\mathrm{PC} 2,+\mathrm{PC} 1$ and $-\mathrm{PC} 2,-\mathrm{PC} 1$ and $+\mathrm{PC} 2,-\mathrm{PC} 1$ and $-\mathrm{PC} 2$ scores were classified as tolerant, moderately tolerant, moderately susceptible, and susceptible, respectively.

Table 4. Principal component Analysis in Basmati rice mutants based on seedling growth traits and yield.

\begin{tabular}{|c|c|c|c|c|c|c|c|}
\hline \multirow[t]{2}{*}{ Variable } & \multicolumn{7}{|c|}{ Principal Component } \\
\hline & PC1 & PC2 & PC3 & PC4 & \multicolumn{2}{|l|}{ PC5 } & PC6 \\
\hline Eigenvalue & 3.186 & 1.779 & 0.467 & 0.384 & \multicolumn{2}{|l|}{0.157} & 0.026 \\
\hline$\%$ of variance explained & 53.1 & 29.7 & 7.8 & 6.4 & \multicolumn{2}{|l|}{2.6} & 0.4 \\
\hline$\%$ of cumulative variance explained & 53.1 & 82.8 & 90.5 & 96.9 & \multirow[t]{2}{*}{99.6} & & 100.0 \\
\hline Trait & \multicolumn{4}{|c|}{ Factor loadings after varimax rotation } & & \multirow{2}{*}{\multicolumn{2}{|c|}{ Communality }} \\
\hline & \multicolumn{2}{|l|}{$\mathrm{F} 1$} & \multicolumn{3}{|l|}{$\mathrm{F} 2$} & & \\
\hline Shoot Length & \multicolumn{2}{|l|}{0.718} & \multicolumn{2}{|l|}{-0.464} & \multicolumn{3}{|c|}{0.732} \\
\hline Shoot Fresh Weight & \multicolumn{2}{|l|}{0.050} & \multicolumn{2}{|l|}{-0.978} & \multicolumn{3}{|c|}{0.959} \\
\hline Shoot Dry Weight & \multicolumn{2}{|l|}{0.057} & \multicolumn{2}{|l|}{-0.974} & \multicolumn{3}{|c|}{0.952} \\
\hline Root Dry Weight & \multicolumn{2}{|l|}{-0.836} & \multicolumn{2}{|l|}{-0.149} & \multicolumn{3}{|c|}{0.722} \\
\hline Cell Membrane Thermo-stability & \multicolumn{2}{|l|}{0.856} & \multicolumn{2}{|l|}{0.005} & \multicolumn{3}{|c|}{0.733} \\
\hline Paddy Yield & \multicolumn{2}{|l|}{0.795} & \multicolumn{2}{|l|}{-0486} & \multicolumn{3}{|c|}{0.869} \\
\hline
\end{tabular}

Table 5. Principal component analysis in Basmati rice mutants based on biochemical parameters and yield.

\begin{tabular}{|c|c|c|c|c|c|c|c|c|}
\hline \multirow[t]{2}{*}{ Variable } & \multicolumn{8}{|c|}{ Principal Component } \\
\hline & PC1 & PC2 & PC3 & PC4 & PC5 & PC6 & PC7 & PC8 \\
\hline Eigenvalue & 2.730 & 1.645 & 1.401 & 1.062 & 0.542 & 0.306 & 0.190 & 0.125 \\
\hline$\%$ of variance explained & 34.1 & 20.6 & 17.5 & 13.3 & 06.8 & 03.8 & 02.4 & 0.16 \\
\hline $\begin{array}{l}\% \text { of cumulative variance } \\
\text { explained }\end{array}$ & 34.1 & 54.7 & 72.2 & 85.5 & 92.2 & 96.1 & 98.4 & 1.000 \\
\hline \multirow[t]{2}{*}{ Trait } & \multicolumn{6}{|c|}{ Factor loadings after varimax rotation } & \multirow{2}{*}{\multicolumn{2}{|c|}{ Communality }} \\
\hline & \multicolumn{2}{|c|}{ F1 } & $\mathrm{F} 2$ & F3 & \multicolumn{2}{|l|}{ F4 } & & \\
\hline POD & \multicolumn{2}{|l|}{0.038} & -0.858 & 0.345 & \multicolumn{2}{|l|}{0.866} & \multicolumn{2}{|l|}{0.966} \\
\hline TPC & \multicolumn{2}{|l|}{0.881} & -0.186 & -0.090 & \multicolumn{2}{|l|}{0.823} & \multicolumn{2}{|l|}{0.823} \\
\hline CAT & \multicolumn{2}{|l|}{0.401} & 0.098 & -0.796 & \multicolumn{2}{|l|}{0.804} & \multicolumn{2}{|l|}{0.804} \\
\hline MDA & \multicolumn{2}{|l|}{0.178} & 0.054 & 0.834 & \multicolumn{2}{|l|}{0.740} & \multicolumn{2}{|l|}{0.740} \\
\hline TSP & \multicolumn{2}{|l|}{0.006} & -0.105 & -0.972 & \multicolumn{2}{|l|}{0.964} & \multicolumn{2}{|l|}{0.964} \\
\hline TOS & \multicolumn{2}{|l|}{0.874} & 0.135 & 0.249 & \multicolumn{2}{|l|}{0.852} & 0.852 & \\
\hline Yield & 0.163 & & -0.890 & -0.262 & 0.050 & & 0.890 & \\
\hline
\end{tabular}



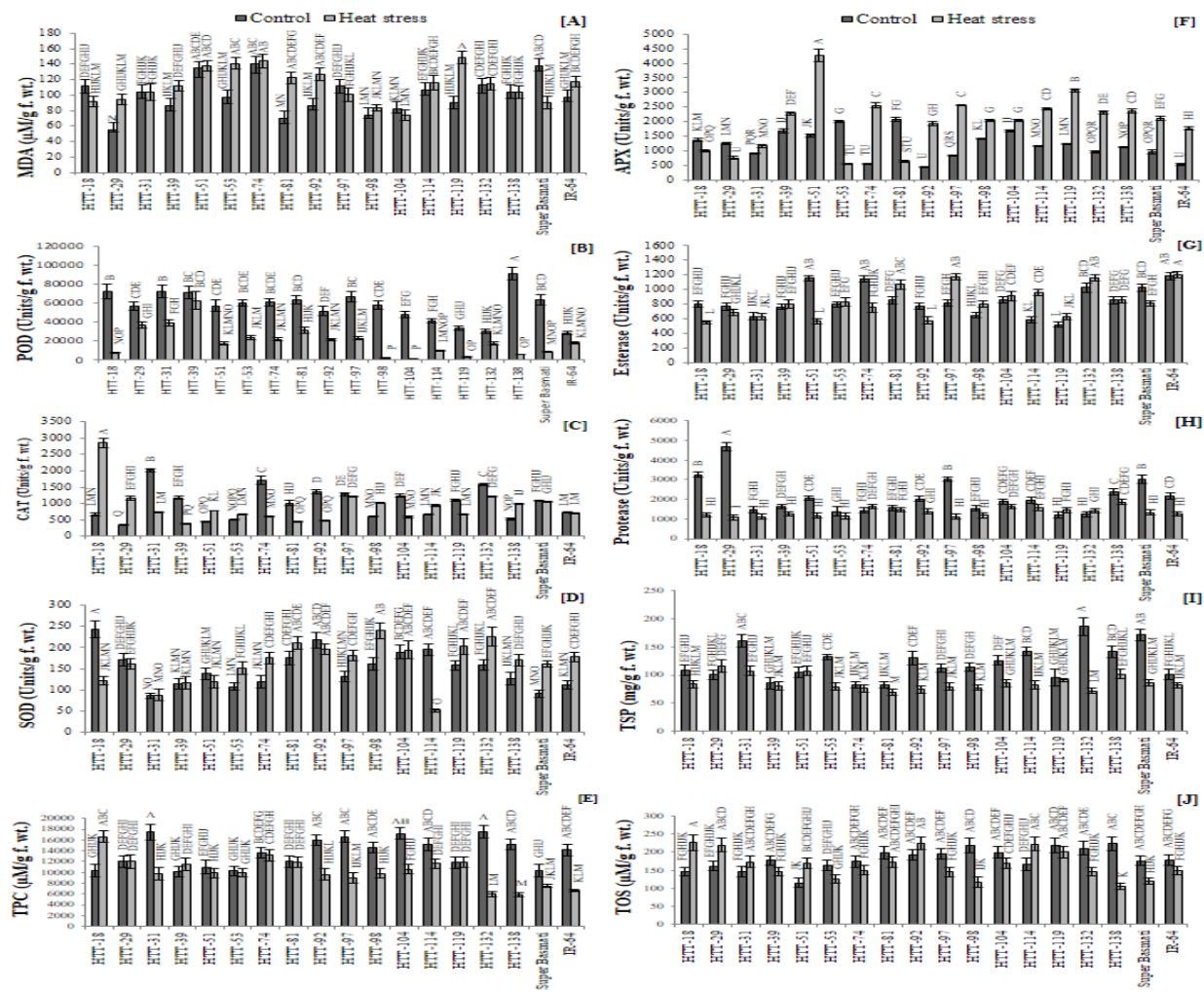

Fig 4. Effect of heat stress on (A) MDA, (B) POD, (C), CAT, (D) SOD, (E) TPC, (F) APX, (G) esterase (H) protease (I) TSP and (J) TOS in Basmati rice mutants.

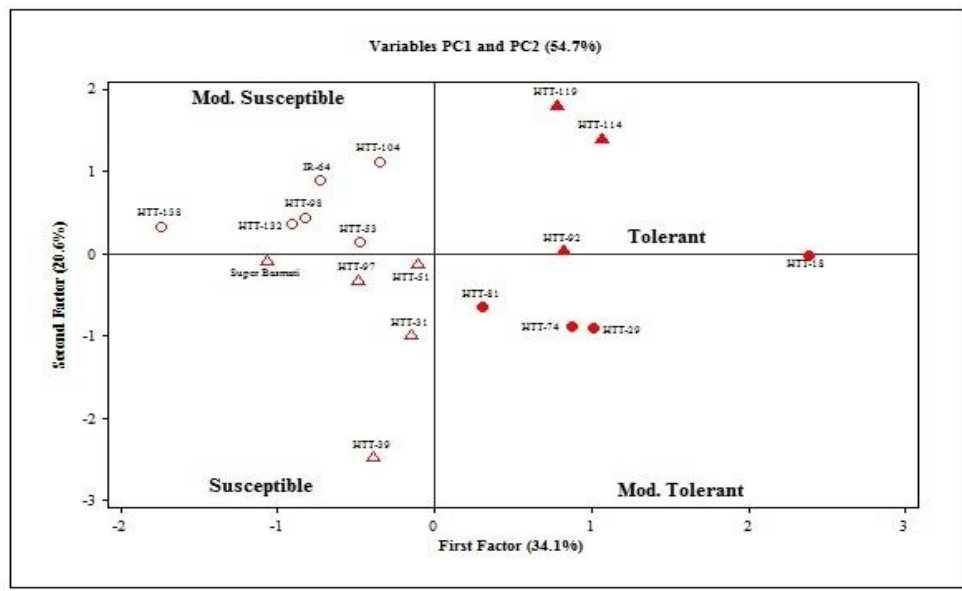

Fig. 5. Classification of Basmati rice mutants based on biochemical parameters. Mutants that had $+\mathrm{PC} 1$ and $+\mathrm{PC} 2,+\mathrm{PC} 1$ and $-\mathrm{PC} 2,-\mathrm{PC} 1$ and +PC2,-PC1 and -PC2 scores were classified as tolerant, moderately tolerant, moderately susceptible, and susceptible, respectively.

According to the productivity under hot field conditions, the mutants HTT-18, HTT-29, HTT-39, HTT-92 and HTT-114 were considered as heat tolerant. Interestingly, the classification of mutants based on PCA using POD, TPC, CAT, MDA, TSP and TOS coincided with the heat tolerance level of mutants grown in the hot field conditions. The important characters coming together in different PCs had the tendency to remain together, which might be kept into consideration during selection for thermo-tolerance.

\section{Materials and Methods}

\section{Screening for heat tolerance in the growth chamber}

A total of 161 Basmati rice mutant lines and advanced mutants of Basmati-370 along with standards Super Basmati and IR-64 varieties were screened to study their physiological responses at seedling stage against high temperature stress $\left(45 \pm 2{ }^{\circ} \mathrm{C}\right)$ for 12 $\mathrm{h}$ along with controls $\left(28 \pm 2{ }^{\circ} \mathrm{C}\right)$ in the growth chamber during the years 2012-14 at NIAB, Faisalabad, Pakistan. The seeds were sown in the plastic pots filled with autoclaved standard compost and in two sets and placed in the growth chamber running at normal temperature $\left(28 \pm 2{ }^{\circ} \mathrm{C}\right)$. Both sets were placed in the dark till the initiation of germination (3-4 days). After germination, 12 $\mathrm{h}$ photoperiod was maintained and one set of six days old seedlings after germination was shifted to another growth chamber for high temperature stress running at $45 \pm 2{ }^{\circ} \mathrm{C}$ for 12 h. After high temperature exposure, the seedlings were allowed to recover for three days by placing them under normal temperature conditions $\left(28 \pm 2{ }^{\circ} \mathrm{C}\right)$ at $12 \mathrm{~h}$ photoperiod. Based 
Table 6. Analysis of variance for different agro-morphological traits in Basmati mutants at NIAB, Multan and Bahawalpur during 2016.

\begin{tabular}{|c|c|c|c|c|c|c|c|c|c|c|}
\hline \multirow{2}{*}{$\begin{array}{l}\text { Source of } \\
\text { variation }\end{array}$} & \multirow{2}{*}{$\begin{array}{l}\text { Degree of } \\
\text { freedom }\end{array}$} & \multicolumn{9}{|c|}{ Mean square } \\
\hline & & $\begin{array}{l}\text { Days to } \\
\text { Flower }\end{array}$ & $\begin{array}{l}\text { Plant } \\
\text { Height }\end{array}$ & $\begin{array}{c}\text { Productive } \\
\text { Tiller } \\
\text { Plant }^{-1}\end{array}$ & $\begin{array}{l}\text { Panicle } \\
\text { Length }\end{array}$ & $\begin{array}{l}\text { Spikelet } \\
\text { Main } \\
\text { Panicle-1 }^{-1}\end{array}$ & $\begin{array}{c}\text { Panicle } \\
\text { Fertilit } \\
\text { y }\end{array}$ & Biomass & $\begin{array}{l}\text { Paddy } \\
\text { Yield }\end{array}$ & $\begin{array}{c}\text { Harvest } \\
\text { Index }\end{array}$ \\
\hline \multicolumn{11}{|l|}{ Replicate } \\
\hline NIAB & 2 & 1.685 & 0.079 & 0.305 & 0.087 & 5.766 & 1.633 & 13727.7 & 40477.384 & 2.586 \\
\hline Multan & 2 & 0.241 & 2.848 & 0.745 & 0.574 & 73.803 & 4.496 & 12452.157 & 2396.487 & 0.099 \\
\hline Bahawalpur & 2 & 2.296 & 0.127 & 26.271 & 0.662 & 60.539 & 0.145 & 35706.1 & 36941.7 & 1.409 \\
\hline \multicolumn{11}{|l|}{ Genotype } \\
\hline NIAB & 17 & $104.9^{* *}$ & $600.9^{* *}$ & $7.8^{* *}$ & $6.1^{* *}$ & $1181.9^{* *}$ & $32.6^{* *}$ & $7976353.6^{* *}$ & $820759.2^{* *}$ & $41.134^{* *}$ \\
\hline Multan & 17 & $151.6^{* *}$ & $450.7^{* *}$ & $8.3^{* *}$ & $10.6^{* *}$ & $1158.6^{* *}$ & $508.5^{* *}$ & $24518568.6^{* *}$ & $866006.4^{* *}$ & $94.728^{* *}$ \\
\hline Bahawalpur & 17 & $166.1^{* *}$ & $701.9^{* *}$ & 44.4 & $6.2^{* *}$ & $613.1^{* *}$ & $280.6^{* *}$ & $4313296.5^{* *}$ & $1047760.7^{* *}$ & $69.7^{* *}$ \\
\hline \multicolumn{11}{|l|}{ Error } \\
\hline NIAB & 34 & 1.215 & 0.373 & 0.180 & 0.124 & 22.227 & 0.000 & 41754.535 & 9761.109 & 0.766 \\
\hline Multan & 34 & 1.319 & 0.758 & 2.355 & 0.665 & 111.603 & 6.008 & 18121.863 & 7504.564 & 1.186 \\
\hline Bahawalpur & 34 & 0.963 & 0.982 & 30.143 & 1.053 & 72.925 & 2.540 & 14158.592 & 13974.615 & 1.275 \\
\hline
\end{tabular}

**\&*: Significant at $\mathrm{p}<0.01$ and 0.01 , respectively

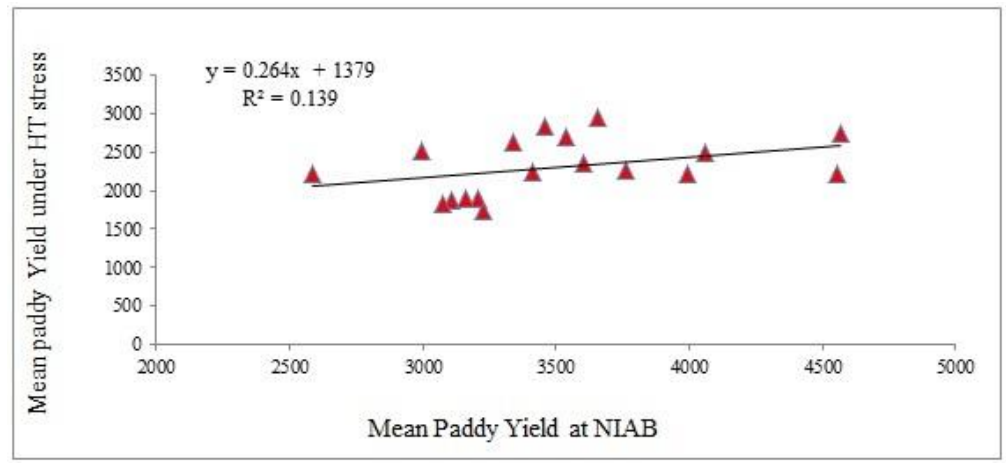

Fig 6. Relationship between paddy yield at NIAB and mean paddy yield under other locations in Basmati rice

on the performance of 161 Basmati rice mutants/lines against high temperature stress during the years 2012-14 trials in the growth chamber, 16 mutants were finally selected exhibiting promise to high temperature stress. During 2015, after seedling emergence of the selected 16 mutants along with Super Basmati and IR-64, $12 \mathrm{~h}$ photoperiod was maintained for two weeks following a completely randomized design with three replications. One set of seedlings was subjected to heat stress for $6 \mathrm{~h}$ daily for 6 days in growth chamber running at $45 \pm 2{ }^{\circ} \mathrm{C}$ while, the other set was kept at normal temperature that served as control. After high temperature exposure, the seedlings were allowed to recover for three days by placing under normal temperature $\left(28 \pm 2{ }^{\circ} \mathrm{C}\right)$ in the growth chamber and data on five random seedlings per replicate were recorded on shoot and root lengths, seedling fresh and dry weights, cell membrane thermostability (CMTS). Fresh weights were recorded immediately after harvesting to avoid evaporation. For dry weight estimations, preweighted seedlings were kept at $72 \pm 2{ }^{\circ} \mathrm{C}$ till complete drying with no further decrease in weight. For biochemical analysis, twenty seedlings (bulk sample) were used. The cell membrane thermo-stability (CMTS) was calculated as follows.

Percent Injury $(\mathrm{PI})=\left[1-\left(1-\mathrm{T}_{1} / \mathrm{T}_{2}\right) /\left(1-\mathrm{C}_{1} / \mathrm{C}_{2}\right)\right] \times 100$ where $\quad \mathrm{T}_{1}: 1^{\text {st }}$ conductivity measurement of heat stressed leaf segments $\left(45^{\circ} \mathrm{C}\right)$.

$\mathrm{T}_{2}: 2^{\text {nd }}$ conductivity measurement (after autoclaving) of heat stressed leaf segments.

$\mathrm{C}_{1}: 1^{\text {st }}$ conductivity measurement of control plant leaf segments $\left(28^{\circ} \mathrm{C}\right)$.

$\mathrm{C}_{2}: 2^{\text {nd }}$ conductivity measurement (after autoclaving) of control plant leaf segments.
CMTS $=100-$ Percent Injury

The stress tolerance indices (STIs) for the above-mentioned traits were calculated as follows.

STI $=\frac{\text { Value under stress }}{\text { Value at control }} \times 100$

The scoring allocations of the mutants were carried out based on cumulative STIs of the seedling traits. Based on cumulative scores of the traits, the scoring was made, and the mutants were ranked as 1,2, and 3, and grouped as tolerant, moderately tolerant and sensitive respectively.

\section{Biochemical Analysis}

For estimation of different stress biomarkers, enzymatic and non-enzymatic antioxidants, hydrolytic enzymes and other biochemical attributes, the methodologies are given below.

\section{Stress biomarkers}

The level of lipid peroxidation in the leaf tissue measured in terms of malondialdehyde (MDA) content was determined by the thiobarbituric acid (TBA) reaction using method of Heath and Packer, (1968) with minor modifications as described by Dhindsa et al. (1981). The MDA content was calculated by using extinction coefficient of $155 \mathrm{mM}^{-1} \mathrm{~cm}^{-1}$. The esterase activity was measured by Fast Blue BB method. The absorbance of colour compound produced was measured at $590 \mathrm{~nm}$ using spectrophotometer (U-2800, 122-003 Hitachi, Japan). Total oxidant status (TOS) was determined by using a novel automated Erel's (2005) formulated method. The absorption of colour compound produced was measured at $560 \mathrm{~nm}$ by using spectrophotometer (HITACHI U-2800). 


\section{Enzymatic antioxidants}

For estimation of enzymes, bulk samples of fresh leaves of twenty-five seedlings $(0.15 \mathrm{~g})$ were ground in cold extraction buffer specific for different enzymes. Samples were centrifuged at $15,000 \times g$ for $20 \mathrm{~min}$ at $4^{\circ} \mathrm{C}$. The supernatant was separated and used for the determination of different enzyme activities and other biochemical assays.

The enzyme activities were expressed on a fresh weight basis. The aactivity of peroxidase (POD) was measured using the method of Chance and Maehly (1955) with some modification. One unit of POD activity was defined as an absorbance change of $0.01 \mathrm{~min}^{-1}$. The ccatalase (CAT) was estimated using the method described by Beer and Sizer (1952). An absorbance changes of $0.01 \mathrm{~min}^{-1}$ was defined as $1 \mathrm{U}$ of CAT activity. For superoxide dismutase (SOD) activity, leaf extracts and analysis are as described by Dixit et al. (2001). The activity of SOD was assayed by measuring its ability to inhibit the photochemical reduction of nitroblue tetrazolium (NBT) following the method of Giannopolitis (1977). One unit of SOD activity was defined as the amount of enzyme that caused $50 \%$ inhibition of photochemical reduction of NBT. The ascorbate Peroxidase Activity (APX) was measured using the method of Dixit et al. (2001). The oxidation rate of ascorbic acid was estimated by following the decrease in absorbance at $290 \mathrm{~nm}$ after every 30 seconds (Chen and Asada, 1989).

\section{Non-enzymatic antioxidants}

Total phenolic content (TPC) was estimated as total phenolics assay by micro colorimetric method (Ainsworth and Gillespie, 2007) which utilizes Folin-Ciocalteau (F-C) reagent. Phenolic content (gallic acid equivalents) of samples was determined using linear regression equation.

\section{Hydrolytic enzymes}

The protease activity was dictated by the casein digestion assay described by Drapeau et al. (1974). By this method one unit is that amount of enzyme, which releases acid soluble fragments equivalent to $0.001 \mathrm{~A} 280$ per minute at $37^{\circ} \mathrm{C}$ and $\mathrm{pH} 7.8$. Enzyme activity was expressed on a fresh weight basis. Esterase activity was measured by the Fast-Blue BB method. The absorbance of color compound produced was measured at 590 $\mathrm{nm}$ using spectrophotometer (U-2800, 122-003 Hitachi, Japan).

\section{Biochemical attributes}

The estimation of total soluble proteins content (TSP) used the method of (Bradford, 1976) using spectrophotometer (HITACHI, U2800).

\section{Evaluation under field conditions}

Based on the performance of 161 Basmati rice mutants/lines at the seedling stage against high temperature stress during the years 2012-15 trials in the growth chamber, 16 mutants were finally selected exhibiting promise to high temperature stress. These mutants were further evaluated in the field following randomized complete block design with three replications at three locations (NIAB, Multan and Bahawalpur) during 2016 and the data were recorded on paddy yield and other agro-morphological traits (days to $50 \%$ flower, plant height, productive tiller per plant, panicle length, spikelets on main panicle, panicle fertility, biomass, paddy yield and harvest index).

\section{Weather data}

The weather conditions at NIAB, Multan and Bahawalpur (temperature, relative humidity and rainfall) for the whole growing season including vegetative and reproductive growth periods during the season 2016 are presented in Fig 1. Both the sites (Multan and Bahawalpur) had higher temperatures than NIAB at vegetative as well as reproductive stage and were relatively hotter than NIAB which affected the productivity of 87 | Page mutants at these locations. The average maximum temperature for the whole growing season ranged from $26.0-45.0^{\circ} \mathrm{C}$ with an average of $36.3^{\circ} \mathrm{C}$ at $\mathrm{NIAB}$, Faisalabad, $24.0-46.0^{\circ} \mathrm{C}$ with an average of $36.9^{\circ} \mathrm{C}$ at Multan and $25.0-45.0^{\circ} \mathrm{C}$ with an average of $37.5^{\circ} \mathrm{Cat}$ Bahawalpur (June-November) while minimum temperature at NIAB, Faisalabad ranged $22.0-31.5^{\circ} \mathrm{C}$ with an average of $27.3^{\circ} \mathrm{C}$ as compared to $22.0-33.0^{\circ} \mathrm{C}$ with an average of $28.9^{\circ} \mathrm{C}$ at Multan and $11.0-31.0^{\circ} \mathrm{C}$ with an average of $24.9^{\circ} \mathrm{C}$ at Bahawalpur. The relative humidity ranged $33.5-86.0 \%$ with an average of $62.9 \%$ at NIAB, Faisalabad, and $23.0-79.0 \%$ with an average of $55.5 \%$ at Multan and $29.0-76.0 \%$ with an average of $53.8 \%$ at Bahawalpur. The total rainfall recorded during the growing season at NIAB, Faisalabad was $585.2 \mathrm{~mm}, 170.2 \mathrm{~mm}$ at Multan and $77.0 \mathrm{~mm}$ at Bahawalpur.

During vegetative stage (June-August), the average maximum temperature range was $31.0-45.0^{\circ} \mathrm{C}$ with an average of $37.9^{\circ} \mathrm{C}$ at NIAB, Faisalabad, $30.0-46.0^{\circ} \mathrm{C}$ with an average of $38.9^{\circ} \mathrm{Cat}$ Multan and $35.0-45.0^{\circ} \mathrm{C}$ with an average of $39.2^{\circ} \mathrm{C}$ at Bahawalpur while minimum temperature at NIAB, Faisalabad ranged 22.0$31.5^{\circ} \mathrm{C}$ with an average of $27.3^{\circ} \mathrm{C}$ as compared to $22.0-33.0^{\circ} \mathrm{C}$ with an average of $28.9^{\circ} \mathrm{C}$ at Multan and $23.0-31.0^{\circ} \mathrm{C}$ with an average of $28.2^{\circ} \mathrm{C}$ at Bahawalpur. The relative humidity ranged $33.5-86.0 \%$ with an average of $63.1 \%$ at NIAB, Faisalabad, 23.0$79.0 \%$ with an average of $55.1 \%$ at Multan and $29.0-76.0 \%$ with an average of $54.0 \%$ at Bahawalpur. The total rainfall recorded during this stage at NIAB, Faisalabad was $261.8 \mathrm{~mm}, 82.1 \mathrm{~mm}$ at Multan and $38.5 \mathrm{~mm}$ at Bahawalpur.

At the flowering/grain-filling stage (September-November), the average maximum temperature range was $26.0-39.0^{\circ} \mathrm{C}$ with an average of $34.6^{\circ} \mathrm{C}$ at NIAB, Faisalabad, $24.0-39.0^{\circ} \mathrm{C}$ with an average of $34.6^{\circ} \mathrm{C}$ at Multan and $25.0-40.0^{\circ} \mathrm{C}$ with an average of $35.5^{\circ} \mathrm{C}$ at Bahawalpur while minimum temperature at NIAB, Faisalabad ranged $9.7-26.5^{\circ} \mathrm{C}$ with an average of $20.5^{\circ} \mathrm{C}$ as compared to $11.0-29.0^{\circ} \mathrm{C}$ with an average of $22.2^{\circ} \mathrm{C}$ at Multan and $11.0-27.0^{\circ} \mathrm{C}$ with an average of $21.0^{\circ} \mathrm{C}$ at Bahawalpur. The relative humidity ranged $47.0-80.0 \%$ with an average of $62.6 \%$ at NIAB, Faisalabad, $33.0-71.0 \%$ with an average of $56.0 \%$ at Multan and $34.0-66.0 \%$ with an average of $53.6 \%$ at Bahawalpur. The total rainfall recorded during this stage at NIAB, Faisalabad was $30.8 \mathrm{~mm}, 3.0 \mathrm{~mm}$ at Multan and $0.0 \mathrm{~mm}$ at Bahawalpur.

\section{Statistical analysis}

The analysis of variance (ANOVA) and correlations were computed using MSTATC statistical programme to determine differences among the mutants for different agronomic and seedling growth traits. The significance of correlation between yield and other agronomic/seedling growth traits was determined at 0.01 and 0.05 levels of probability.

Principal component analysis (PCA) was performed using mean values to find traits accounting for phenotypic variation as well as to classify the mutants for heat tolerance using computer software "Minitab 14" for Windows. For PCA, procedures of Chatfield and Collin (1980), Mahloch (1974), Mazlum (1994), and Mazlum et al. (1999) were followed. The component loadings (correlation coefficients) and the variances (eigenvalues) regarding the components were computed for all the characters at the first step following a correlation matrix as all the traits had equal importance with different scales. The proportion of the total variance explained by each principal component was additive, with each new component contributing less than the preceding one to the explained variance. According to Brejda et al. (2000), data were considered in each component with eigenvalue $>1$ which determined at least $10 \%$ of the variation. The higher eigenvalues were considered as best representatives 
of system attributes in principal components. Subsequently, the components were selected whose eigenvalue $(\lambda)$ was $>1$, and varimax rotations were performed until all the communalities were $\sim 0.7$. The values of only yield-correlated seedling growth traits (shoot length, root length, shoot dry weight, root fresh and dry weights, and cell membrane thermo-stability) were included in the PCA. The eigenvalues generated by PCA were used to grade mutants for their heat tolerance. The first two PC scores (PC1 and PC2), accounted for maximum variability of the parameters tested, were used to classify the mutants. The mutants that had +PC1 and +PC2 scores were classified as tolerant, those with +PC1 and - PC2 scores as moderately tolerant, those with $-\mathrm{PC} 1$ and +PC2 scores as moderately susceptible, and those with -PC1 and -PC2 scores as susceptible following Kakani et al. (2005).

\section{Conclusion}

Several studies revealed that high temperature damage to plants was caused by the excessive production of reactive oxygen radicals and consequent low activities of antioxidant enzymes and the cell membrane damage (Zhang et al., 2006 and Zhu et al., 2005) and ultimately yield. The decrease in antioxidant activity under stressed conditions resulted in higher levels of ROS that might contribute to cell injury (Fadzillah et al., 1996). The present studies revealed that screening for seedling growth related traits (shoot length, shoot fresh and dry weight and cell membrane thermo-stability), and trends of biochemical parameters at the seedling stage might support the selection for thermo-tolerance in rice. The results of the growth-related traits and biochemical parameters coincided favourably with yield data under hot field conditions. In this study, the levels and activities of MDA, SOD, APX and esterase increased/maintained over control indicating higher production of ROS under high temperature stress.

\section{Acknowledgements}

The authors are thankful to the International Atomic Energy Agency (IAEA) for providing technical and financial support through Coordinated Research Project (CRP) Pak-16589 "Breeding for high yielding long rain rice with adaptation to high temperatures" under an IAEA-CRP (D-23029) "Climate Proofing of Food Crops: Genetic Improvement for Adaptation to High temperatures in drought prone areas and beyond "

\section{References}

Ainsworth EA, Gillespie KM (2007) Estimation of total phenolic content and other oxidation substrates in plant tissues using Folin-Ciocalteu reagent. Nature Protocols. 2: 875-877.

Ainsworth E A, Ort D R (2010) How Do We Improve Crop Production in a Warming World? Plant Physiol. 154: 526-530.

Ali F, Waters DLE, Ovenden B, Bundock P, Raymond CA, Rose TJ (2018) Australian rice varieties vary in grain yield response to heat stress during reproductive and grain filling stages. J Agro Crop Sci. 1-9.

Ali MK, Azhar A, Galani S (2013) Response of rice (Oryza sativa L.) under elevated temperature at early growth stage: Physiological markers. Russian J Agric Socio-Econ Sci. 20: 1119.

Almeselmani M, Deshmukh PS, Sairam RK, Kushwaha SR, Singh TP (2006) Protective role of antioxidant enzymes under high temperature stress. Plant Sci. 171: 382-388.

Bahuguna RN, Jha J, Pal M, Shah D, Lawas LMF, Khetarpal S, Jagdesh KSV. (2015) Physiological and biochemical characterization of NERICA-L-44: a novel source of heat tolerance at the vegetative and reproductive stages in rice. Physiol Planta. 154: 543-559.
Bahuguna RN, Chaturvedi AK, Pal M (2016) Physiological traits for improving high temperature stress tolerance in rice. Ind J Plant Physiol. 21(4): 420-427. Beers RF, Sizer IW (1952) A spectrophotometric method for measuring the breakdown of hydrogen peroxide by catalase. J Biol Chem. 195: 133-140.

Bita C, Gerats T (2013) Plant tolerance to high temperature in a changing environment: scientific fundamentals and production of heat stress-tolerant crops. Front Plant Sci. 4(article 273): 118.

Bradford MM (1976) A rapid and sensitive method for the quantitation of microgram quantities of protein utilizing the principle of protein-dye binding. Anal Biochem. 72: 248-254.

Brejda JJ, Moorman TB, Smith JL, Karlen DL, Allan DL, Dao, TH (2000) Distribution and variability of surface soil properties at a regional scale. Soil Sci Soc Amer J. 64(3): 974982.

Cao YY, Duan H, Yang LN, Wang ZQ, Liu LJ, Yang JC (2009) Effect of high temperature during heading and early filling on grain yield and physiological characteristics in Indica rice. Acta Agron Sin. 35: 512-521.

Chance B, Maehly A (1955) Assay of catalases and peroxidases. Methods Enzymol. 2: 764-775.

Charng YY, Liu HC, Liu NY, Chi WT, Wang CN, Chang SH (2007) A heat-inducible transcription factor, HsfA2, is required for extension of acquired thermo tolerance in Arabidopsis. Plant Physiol.143: 251-262.

Chatified C, Collin AJ (1980) Introduction to multivariate analysis. Chapman and Hall in association with Methuen. Inc. 733, Third Avenue, New York NY. 10017.

Chaturvedi AK, Bahuguna RN, Shah D, Pal M, Jagadish SVK (2017) High temperature stress during flowering and grain filling offsets beneficial impact of elevated $\mathrm{CO}_{2}$ on assimilate partitioning and sink strength in rice. Sci Rep. 7: 1-13.

Chen GX, Asada K (1990) Hydroxyurea and p-aminophenol are the suicide inhibitors of ascorbate peroxidase. J Biol Chem. 265: 2775-2781

Collins NC, Tardieu F, Tuberosa R (2008) Quantitative trait loci and crop performance under abiotic stress: Where do we stand? Plant Physiol. 147: 469-486.

Demirel U, Copur O, Gur AA (2016) Early-stage screening for heat tolerance in cotton. Plant Breed. 135: 80-89.

Dhindsa RS, Plumb-Dhindsa P, Thorpe TA (1981) Leaf senescence: correlated with increased levels of membrane permeability and lipid peroxidation, and decreased levels of superoxide dismutase and catalase. J Exp Bot. 32: 93-101.

Dixit V, Pandey V, Shyam R (2001) Differential antioxidative responses to cadmium in roots and leaves of pea (Pisum sativum L. cv. Azad). J Exp Bot. 52: 1101-1109.

Drapeau G R (1976) Protease from Staphylococcus aureus. Methods Enzymol. 45: 469-75.

Erel O (2005) A new automated colorimetric method for measuring total oxidant status. Clin Biochem., 38: 1103-1111.

Fadzillah NM, Gill V, Finch RP, Burdon RH (1996) Chilling, oxidative stress and antioxidant responses in shoot cultures of rice. Planta. 199: 552-556.

Giannopolitis CN, Ries SK (1977) Superoxide dismutases I. Occurrence in higher plants. Plant Physiol. 59: 309-314.

Hall AE (2011) Breeding cowpea for future climates. In: Yadav SS, Redden R, Hatfield JL, Lotze-Campen H, Hall AJW (eds) Crop adaptation to climate change, John Wiley \& Sons.

Hameed A, Goher M, Iqbal N (2012) Heat stress-induced cell death, changes in antioxidants, lipid peroxidation, and protease activity in wheat leaves. J Plant Growth Regul. 31: 283-291.

Heath RL, Packer L (1968) Photoperoxidation in isolated chloroplasts I. kinetics and stoichiometry of fatty acid peroxidation. Arch Biochem Biophys. 125: 189-198. 
Howarth CJ (2005) Genetic improvement of growth and survival at high temperature. In: Ashraf M, Harris PJC (eds) Abiotic stresses: Plant resistance through breeding and molecular approaches, Haworth Press Inc, New York.

IPCC (2013) Working group I Contribution to the IPCC fifth assessment report climate change: The physical science basis, summary for policy makers. Available on line at http://www.Climatechange 2013.Org/ images/ report/WG1AR5_SPM_FINAL.pdf

Iqbal N, Farooq S, Arshad R, Hameed A (2010) Differential accumulation of high and low molecular weight heat shock proteins in basmati rice (Oryza sativa L.) cultivars. Genet Resour Crop Evol. 57: 65-70.

Johnson DE (1998) Applied multivariate methods for data. Johnson/Duxbury Press, New York.

Jumiatun, Junaedi A, Lubis I, Chozin MA, Miyazaki A (2016) Morphological, physiological and yield responses of some rice varieties (Oryza sativa L.) as exposed under high temperature in Indonesia. American J Plant Physiol. 11: 33-41.

Kakani VG, Reddy KR, Koti S, Wallace TP, Prasad PVV, Reddy VR (2005) Differences in in vitro pollen germination and pollen tube growth of cotton cultivars in response to high temperature. Ann Bot. 96: 59-67.Kang HM, Saltveit ME (2002) Antioxidant enzymes and dpph-radical scavenging activity in chilled and heat-shocked rice (Oryza Sativa L.) seedlings radicles. J Agric Food Chem. 50: 513-518.

Kumar N, Kumar N, Shukla A, Shankhdhar SC, Shankhdhar D (2015) Impact of terminal heat stress on pollen viability and yield attributes of rice (Oryza sativa L.). Cereal Res Comm. 43(4): 616-626.

Liu Z, Yuan YL, Liu SQ, Yu XN, Rao LQ (2006) Screening for high-temperature tolerant cotton cultivars by testing in vitro pollen germination, pollen tube growth and boll retention. J Integ Plant Biol. 48: 706-714.

Liu QH, Wu X, Li T, Ma JQ, Zhou XB (2013) Effects of elevated air temperature on physiological characteristics of flag leaves and grain yield in rice. Chilean J Agric Res. 73: 85-89.

Maestri E1, Klueva N, Perrotta C, Gulli M, Nguyen HT, Marmiroli N (2002) Molecular genetics of heat tolerance and heat shock proteins in cereals. Plant Mol Biol. 48(5-6): 66781

Mahloch JL (1974) Multivariate technique for water quality analysis. J Environ Eng Div. Amer. Soc. Civil Eng. 100(EE5): 1119-1124.

Mazlum N. 1994. Multivariate analysis of water quality data. M. Sc. thesis submitted to Dokuz Eylul University, Graduate School of National and Applied Sciences, Bornova, Izmir.

Mazlum N, Ozer A, Mazlum S (1999) Interpretation of water quality data by principal component analysis. Tr J Eng Environ Sci. 23: 19-26.

Mohammed AR, Tarpley L (2009) Impact of high nighttime temperature on respiration, membrane stability, antioxidant capacity, and yield of rice plants. Crop Sci. 49: 313-322.

Mohammed AR, Tarpley L (2011) Effects of night temperature, spikelet position and salicylic acid on yield and yield-related parameters of rice (Oryza sativa L.) plants. J Agron Crop Sci. 197: 40-49.

Ohe I, Saitoh K, Kuroda T (2007) Effects of high temperature on growth, yield and dry-matter production of rice grown in the paddy field. Plant Prod. Sci. 10: 412-422.

Prasanth VV, Chakravarthi DVN, Kiran TV, Rao YV, Panigrahy M, Mangrauthia SK, Viraktamath BC, Subrahmanyam D, Voleti SR, Sarla N (2012) Evaluation of rice germplasm and introgression lines for heat tolerance. Annals Biol Res. 3(11): 5060-5068.

Ramesh R, Ramesh T, Rao PRV, Shankar G. Bhave MHV (2017) High temperature stress effected the biochemical parameters of rice (Oryza sativa L.) varieties and hybrids. Int J Pure App Biosci. 5(4): 1478-1490.
Ray DK, Gerber JS, MacDonald GK, West PC (2015) Climate variation explains a third of global crop yield variability. Nature commun. 6.

Sailaja B, Anjum N, Prasanth VV, Voleti SR, Subrahmanyam D, Sarla N (2014) Comparative study of susceptible and tolerant genotype reveals efficient recovery and root system contributes to heat stress tolerance in rice. Plant Mol Biol Rep. 32: 12281240.

Sailaja B, Subrahmanyam D, Neelamraju S, Vishnukiran T, Rao YV, Vijayalakshmi P (2015) Integrated physiological, biochemical, and molecular analysis identifies important traits and mechanisms associated with differential response of rice genotypes to elevated temperature. Front Plant Sci. 6: 1-13.

Shah F, Huang J, Cu IK, Nie L, Shah T, Chen C, Wang K (2011) Impact of high temperature stress on rice plant and its traits related to tolerance. J. Agr. Sci. 149: 545-556.

Shah F, Nie L, Cui K, Shah T, Wu W, Huang J (2014) Rice grain yield and component responses to near $2^{\circ} \mathrm{C}$ of warming. Field Crops Res. 157: 98-110.

Shalata A, Neumann PM (2001) Exogenous ascorbic acid (vitamin $\mathrm{C}$ ) increases resistance to salt stress and reduces lipid peroxidation. J Exp Bot. 52: 2207-2211.

Shi W, Ishimaru T, Gannaban RB, Oane W, Jagadish SVK (2014) Popular rice (Oryza sativa L.) cultivars show contrasting responses to heat stress at gametogenesis and anthesis. Crop Sci. 55: 589-596.

Tayade R, Nguyen TD, Oh SA, Hwang YS, Yoon IS, Deshmuk R, Jung KH, Park SK (2018) Effective strategies for enhancing tolerance to high-temperature stress in rice during the reproductive and ripening stages. Plant Breed Biotech. 6(1): 118.

Van Oort, PAJ, Zwart SJ (2018) Impacts of climate change on rice production in Africa and causes of simulated yield changes. Glob Chang. Biol. 24: 1029-1045.

Venkateswarlu B, Visperas RM (1987) Solar radiation and rice productivity. Res Paper Sers No. 129. IRRI, Manila, Philippines.

Wahid A, Gelani S, Ashraf M, Foolad MR (2007) Heat tolerance in plants: An overview. Environ Exp Bot. 61: 199-223.

Wassmann R, Jagadish SVK, Heuer S, Ismail A, Redona E, Serraj R, Singh RK, Howell G, Pathak H, Sumfleth K (2009) Climate change affecting rice production: the physiological and agronomic basis for possible adaptation strategies. Adv. Agron. 101: 59-122.

Xia MY, Qi HX (2004) Effects of high temperature on the seed setting percent of hybrid rice bred with four male sterile lines. Hubei Agric Sci. 2: 21-22.

Yang HC, Huang ZQ, Jiang ZY, Wang XW (2004) High temperature damage and its protective technologies of early and middle season rice in Anhui province. J Anhui Agric Sci. 32: 3-4.

Yang Z, Zhang Z, Zhang T, Fahad S, Cui K, Nie L, Peng S, Huang J (2017) The effect of season-long temperature increases on rice cultivars grown in the central and southern regions of china. Front Plant Sci. 8: 1-15.

Zafar SA, Hameed A, Khan AS, Ashraf M (2017) Heat shock induced morpho-physiological response in indica rice (Oryza sativa L.) at early seedling stage. Pak J Bot. 49(2): 453-463.

Zhang GZ, Chen LY, Zhang ST, Xiao YH, He ZZ, Lei DY (2006) Effect of high temperature stress on protective enzyme activities and membrane permeability of flag leaf in rice. Acta Agron Sin. 32: 1306-1310.

Zhang G, Chen L, Zhang S, Zheng H, Liu G (2009) Effects of high temperature stress on microscopic and ultrastructural characteristics of mesophyll cells in flag leaves of rice. Rice Sci. 16: 65-71. 
Zhou WH, Xue DW, Zhang G (2012) Identification and physiological characterization of thermo-tolerant rice genotypes. J Zhejiang Univ. 38: 1-9.
Zhu CL, Xiao YH, Wang CM, Jiang L, Zhai HQ, Wan JM (2005) Mapping QTLs for heat tolerance during grain filling in rice. China J Rice Sci. 19: 117-121. 